Journal of

Education and Practice (JEP)

UNIVERSITY ADMINISTRATION IN NIGERIA: HISTORY, ETHICS AND CORPORATE GOVERNANCE

Bakare K. A

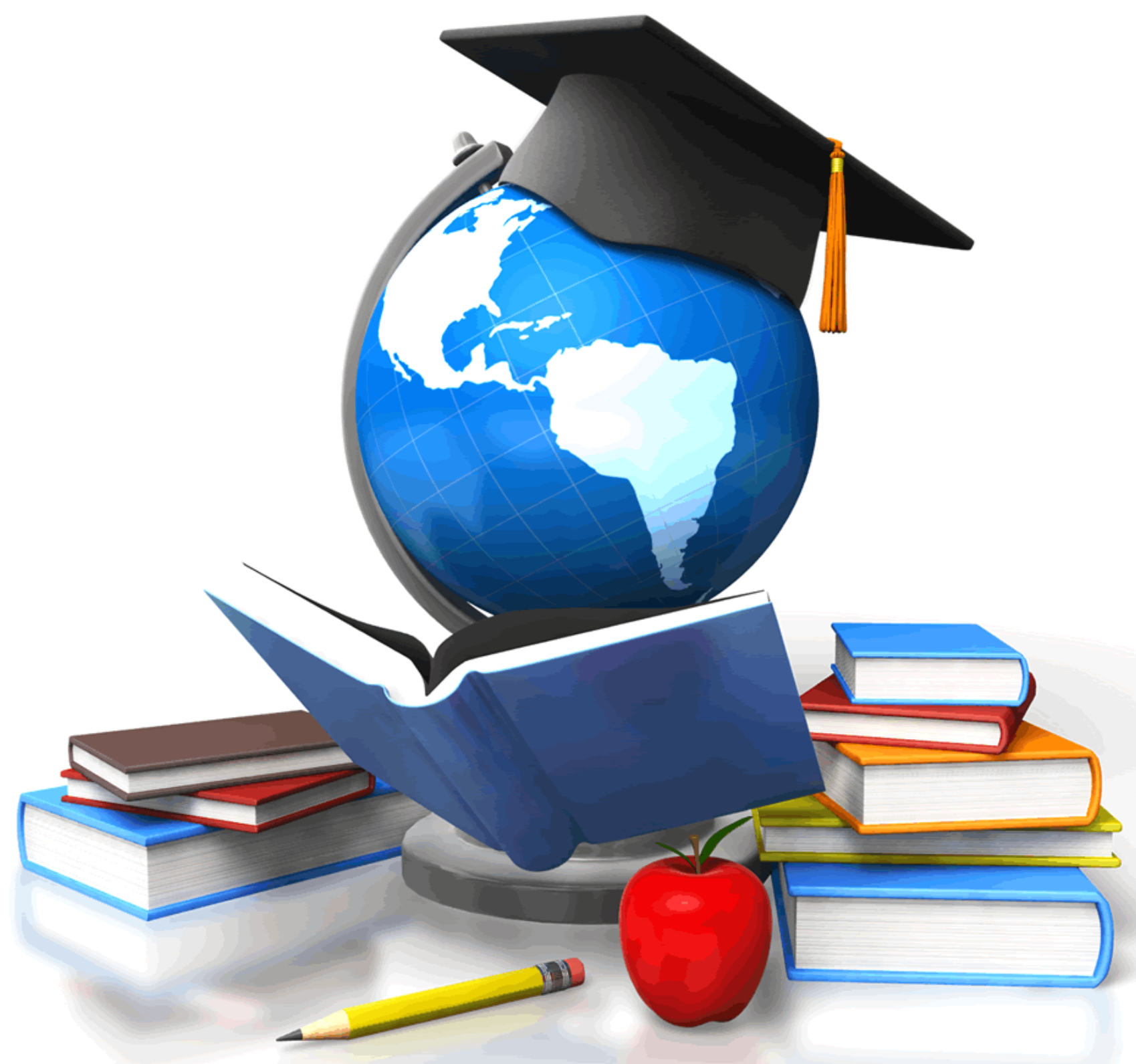

CARI 


\title{
UNIVERSITY ADMINISTRATION IN NIGERIA: HISTORY, ETHICS AND CORPORATE GOVERNANCE
}

\author{
K. A. Bakare \\ Deputy Registrar \\ Obafemi Awolowo University, Ile-Ife \\ Corresponding Author's Email: tunjibakare@yahoo.com
}

\begin{abstract}
Purpose: This paper is an exploratory work focusing on university administration in practice. The study interrogates ethics and practice of university administration in Nigeria, vis-à-vis service-delivery. It captures and exemplifies the nature and elements of university administration as experienced in the contemporary Nigerian polity, making references to aspects of industrial and organizational psychology, human factor psychology, and others, in the context of diverse interrelationships between theory and practice. It reverts to antecedents of administrative practice, tracing the primal formation of organizational styles to the colonial era in British tropical dependencies, and deftly concludes that the contemporary administrative policies were direct derivatives from the political culture of the colonial masters who sought to enforce "law and order" and through a self-imposed dual mandate sophistry. It concludes by drawing attention to observed infractions in the contemporary practice, and emphasized on the need to upgrade ethics, practice and corporate governance. Contributions on the socio-politics of corporate practice in Nigerian universities is paltry, and more research could be initiated in this area to complement our effort.
\end{abstract}

Methodology: The research design is descriptive, focusing on answering the how, what, when and where, (i.e. in addition to why) thus, providing rooms for examination of historical evidences, theoretical relevance and practical algorithms. The study used qualitative research method to properly describe the research problem and analyzed the problem based on observed characteristics, behaviours and reactions. The researcher being an active participant in the system, used the instruments of interactive sessions, seminars, workshops and interviews.

The study was carried out among a cross-section of administrative class who are employees in renowned government-run public universities in Nigeria and are being governed by the same regulations under the jurisdiction of the National Universities Commission and the Federal Government of Nigeria. The target population of the work are the academic administrators, the professional administrators, as well as scholars of educational studies in HEIs. A survey is conducted to validate our stance on compromised standards, and to posit measures that reassert good practice, using the qualitative research method to succinctly describe the research problem by observing the dialectical nuances of the work environment and drawing farreaching conclusions on the contemporary state of management and administration in our universities. The research is hinged on social exchange theory (SET) which overtly describes the relationship between an organization and its employees in a social context (Blau, 1964; Molm and Cook, 1995; Azim, 2016), while at the same time, extending the social interface description to the individual level to describe relationships between supervisors and subordinates in a leader-member exchange (LMX theory) background (Manzoni and Barsoux, 2002). 
Journal of Education and Practice

ISSN 2520-467X (Online)

Vol.5, Issue No.2, pp $30-44,2021$

www.carijournals.org

Results: The study revealed that ethics and corporate culture have become compromised due to decades of abstruse practices, and that there was the need to urgently revamp work ethics, re-align values and re-orient practice in order to catch up with the meteoric speed of the global space. The nuances and intricacies involved in creating and maintaining standards, and the necessity of recreating a virile work culture is incontestable, not forgetting that our colonial antecedent also provided a skewed background for the practice.

Unique contribution to theory, policy and practice: It was recommended that negatives like excessive bureaucracy should be jettisoned, and open-door policies should displace shoehorned policies of government. Our universities should be nurtured and encouraged to self-regulate, while modern management technique should be entrenched in the system. In order to be able to effectively deliver on their triadic mandates of teaching, research and community services, the workforce in the universities should be adequately motivated and a strong reward system should be put in place to galvanize excellence. The National Policy of Education should be constantly reviewed in tandem with new-age realities, while aggressive digitization should be introduced to simplify operations, reduce stress, and maximize service-delivery.

Key words: ethics, university administration, service-delivery, psychology, theory and practice, corporate governance

\subsection{Introduction}

Taking up a new job ordinarily requires one primary observance; to ask oneself why one is interested in taking up that particular job. One should be able to ask, why this job and not that job? In recent times, job-seekers in Nigeria have not been given that luxury, as most of them are economic hitch-hikers, content with any kind of job to get food on the table. This skewed beginning, imposed on them by economic necessity has created much apathy in the system, thus producing a host of people hibernating on a profession, content with living from paycheck to paycheck. Confounding situations like antagonistic government policies, non-payment of salaries, constant threats of retrenchment, recruitment impunities and others, culminated mostly to ill-motivated workforce, and the consequent drop in standards and work ethics. Deadend officers populate the system to mark time and 'take a bow' at the appropriate time when it is time to retire.

Corporate governance is a tool used to bring together all contending interests and form a common ground in every organization. However, in our crises-prone universities, elements of disagreement have taken precedence over good governance as expressed though strikes, brain drain and features that have greatly emasculated our image. Dissonance are fomented as a result of inadequate funding, overarching political interference, skewed laws and aberrant leaderships. (Issa Abdulraheem, 2014). As a result, effectiveness of the system both administratively and academically, had mostly become compromised especially, in public universities. A platform was thereby presented for rivalry and competition between the public and private universities, devoid of a level-playing ground.

\subsection{Statement of the Problem}

Good ethics and corporate governance remain the dual bastions of success for all organizations, knowledge corporations inclusive. Though corporate practice in Nigerian universities is neoWeberian, a number of weaknesses and challenges had crept in due to bland and inappropriate practice. These had impacted negatively on effective and efficient service-delivery, hence, the reversal of gains acquired in halcyon times. Lack of professionalism, depraved value-matrices, 
Journal of Education and Practice

ISSN 2520-467X (Online)

Vol.5, Issue No.2, pp $30-44,2021$

WWW.carijournals.org

backdoor policies, compromised standards, defective environment and lack of state-of-the-art tools to work with had conjoined to produce a class of ill-motivated workforce. In view of this decline, it has become important to begin to look for means to rejig the practice and revamp ethical standards.

\subsection{Literature Review}

Maintaining standards in any human endeavor is as important as attaining standards. In human resource management, standard is not negotiable, as the absence of it forecasts doom for the organization. The nexus rests heavily on synergy and good practice to achieve and deliver on target plans and mandates. Henri Fayol (1916) changed the orientation of management practice by defining the nubilous topic along the lines of principles and functions. But it was not until the seminal attempt of Luther Gulick and Lyndall Urwick (1937) that HR studies assumed a clearer nature and scope in terms of functionality. In the universities, intensified competition between the public and the private sectors engendered by globalization, social lines, decline of standards and diverse mindsets had completely brought about a paradigm shift towards acquisition of knowledge

In public universities, heavyweight bureaucrats and stagnant business have become a constant variable that has brought about the call for downsizing from certain quarters, or the scrapping of what some people envisaged as 'all-administrative universities,' signifying that vision, mission and strategic planning have gone awry. Also, for organizations seeking efficiency, corporate governance is ensconced to harmonize divergent interests between the management the boards and other stakeholders, to ameliorate tensions (Demidenko and McNutt, 2010). In our universities where government, management, students and parents are major stakeholders, brazen challenges are caused mainly by shoehorned policies of government and insincerity of stakeholders (Bakare, K.A.).

\subsection{Diachronic Perspective}

Writing in the introduction to his seminal book, Ogunruku (2012) conceded that knowledge of the past in every sphere, especially as it concerned university administration, is germane for proper understanding of administration in general. In order to put administration in its proper perspective, it is important to trace the history of its entrenchment in Nigeria to the civil service of the colonial era, which evolved from the $18^{\text {th }}$ century till present.

\subsection{Servants of the Crown}

In the $18^{\text {th }}$ century, the British Empire witnessed a sudden and unprecedented growth through expansionist drive outside its immediate geographical enclave. Holding onto the self-deluding mantra of civilizing mission, the incursions made into the enclaves later known as British African dependencies saw to the introduction of new forms of cultural values and organizational process. The "dual mandate" of the colonial adventurers and the self-serving escapades wrapped in a rosy veil came with the primal intents to expropriate economic benefit for the British Empire and to impose governance and administration on the natives through indirect rule (Lugard, 1922). The value matrices of the colonized were changed drastically, and the supremacist culture was entrenched through force, chicaneries and "law and order" administration. Hence, the civil service became ensconced in the polity as the instrument of the colonizers to govern, administer and make use of the colonized for the political and economic agenda of the colonizers. The civil service which started on a petty note to train and make use of clerks, interpreters, constables, etc. soon became enlarged and challenged as a result of growth and the need to enlarge service-delivery, enroll services of the growing numbers of 
Journal of Education and Practice

ISSN 2520-467X (Online)

Vol.5, Issue No.2, pp $30-44,2021$

www.carijournals.org

native elites, and overhaul the structure to accommodate the size. This development saw to the need to appoint more staff which was done mostly, by patronage. The system soon started experiencing stasis as merit was thrown overboard. By 1854, the Northcote-Trevelyan Report (Dare, L.O. \& Oyewole A., 1976) recommended a politically-neutral civil service with appointments strictly based on merit, and a division between the technical or mechanical class of workers, and the administrative class involved in policy formulation and policy implementation. With the bureaucratic chaos of the Post- Crimean War, attempts were made to reverse the decay in the civil service. In 1855, a civil service Commission was set up to

“...oversee open recruitment and end patronage.” (Dare, L.O. \& Oyewole A., 1976)

The Northcote-Trevelyan model remained tenable as it was continually revisited by different commissions and its recommendations recycled, suggested or implemented until 1968, when the aftermath of the Second World War prompted further demands for a sweeping reform in the civil service, and the Lord Fulton Commission was set up to rework the service. The commission identified that as a result of the cancerous patronage appointment and the complexities of the contemporary experiences, the usual good all-rounder administrator could no longer cope with the increasing professional demands of the job, and that the high-up ivy league administrative class, the staff usually referred to as "the mandarins," were too insulated and high-nosed to midwife effective service-delivery. It was recommended that the positions of the experts, i.e. the professionals should be rationalized while a unified grading system should be adopted for all category of staff. (Dare, L.O. \& Oyewole A., 1976)

Margaret Thatcher (1979) was an advocate of free market social system, and identified with the openness and democratization of the civil service. She reduced the size of the civil service drastically, and sought to appoint Derek Rayner (1982), as efficiency expert, with a view to getting the senior civil servants to focus on efficient management. Michael Heseltine (1982), advocated performance-related pay (PRP) to motivate and galvanize efficiency, while Robbin Ibbs (1983), introduced a new approach to service-delivery which entailed working on targets and taking personal responsibility. In all, the tendency towards getting civil servants to take a commercial approach and achieve improved efficiency through privatization and marketdriven autonomy could be deciphered across all models, starting with the Northcote-Trevelyan model to the reformist policies of Margaret Thatcher. All of them agreed on the insularity and the ineffectual disposition of the civil service, and the need to revamp the service and introduce positive orientations. (Her Majesty's Civil Service, 2021)

\subsection{Law and Order Administration}

In British tropical dependencies, especially in Nigeria, the colonial civil servants were employed mainly to entrench a structure complementing law and order for the system, hence, there was no multiplicity of efforts or multi-tasking outside the onerous focus to synergize all activities for the benefits of the British Imperial Majesty. At that time, to underline the unilateral task of enforcing law and order among the natives, the 1914 tripartite Secretariat arrangement was a single building that was used to serve as the sole repository of records and the only channel of communication with the Governor. However, with the advent of the new African civil service elites shortly after independence, the civil service became more professional, as there arose the need to tackle more than one indigenous interests. There was therefore, the immediate need for the entrenchment of a civil service that would meet the emerging challenges of a development-oriented status of the newly independent nation, and 
Journal of Education and Practice

ISSN 2520-467X (Online)

Vol.5, Issue No.2, pp $30-44,2021$

WWW.carijournals.org

that would diversify to such areas like personnel management, financial management, planning and statistics as well as other relevant areas of the profession (I.M. Okonjo, 1975)

The Westminster construct which was transposed to the colonized terrain saw administration or the civil service as an all-comer affair where every averagely-educated person could fit in. This generalist view which subsists in the civil service even till the present day tends to address the service with open-ended approach such that it half-consciously downplayed professional training for the skills of the average pen-pushers. Some of the legacies bequeathed on the civil service and had stuck till present day include the conception that civil servant should stand outside the mainstream of action in order to remain professional, that, they should be seen and not be heard (L.O. Dare and A. Oyewole, 1976).

Another is the way the Westminster model delineated between the professional cadre and the administrative cadre and divided them into classes, with limited career prospects for the clerical, executive and the secretarial classes. The Fulton Commission of 1968 rejected the generalist view of the civil service and proposed that traditional division of the British Civil service into Administrative and Professional cadres should be abandoned in favour of a single cadre. In other words, the nature and ambience of the job called for a unified service rather than antagonistic stratification propagated by the Westminster model. (I.M. Okonjo, 1975)

The transition from the 'law and order' administration of pre-independence to the professionally-inclined seasoned administration of the post-independence era had ensured the move from routinized administration' to 'development administration, as there emerged the greater need for the increased role of the civil servant to fit into the variegated post-independent requirements of the civil service. The wave of wage-earning agitations that followed shortly in turn, ensured improved welfare services for workers through the Simeon-Adebo and Udoji Commissions, as the purchasing power of workers received a boost, which in turn ensured and enhanced a buoyant national economy; though, some people argued to the contrary, that the boost actually triggered the demise of professionalism and the cancerous spread and proliferation of heightened agitations for increased wages in the civil service. (I.M. Okonjo, 1975) In general, a number of attributes had been carried over from the pre-independence colonial civil service to the present civil service, and by implication, to university administration. It may be argued that while some of them are artificial, a number of them are germane requirements of seasoned administrative executives. One of them is the clinical stance that an executive should maintain with the employer. For instance, by tradition, the Western State Civil Servants were schooled to be non-political in their public life. In the handbook for new entrants into the Western Regional Public Service, it was specifically spelt out that:

As a Civil Servant, you must never forget that however well-qualified and expert you may become in your job, you have not been elected to it by any vote; and in a democratic country, it is the elected representative... who must settle the lines on which the government of the community is to work. In other words, as a civil servant, you are not entitled to do things according to your personal taste just because it is your personal taste [emphasis added].You must do what the Regional Legislature wants you to do...Y Your loyalty is to the Minister of the day. If and when a different party comes to power, your new Minister may require radical changes in the policy of your Ministry. Your duty is to carry out new policy with the same loyalty as you gave the old. (L.O. Dare and A. Oyewole, 1976, p.127) 
Journal of Education and Practice

ISSN 2520-467X (Online)

Vol.5, Issue No.2, pp $30-44,2021$

WWW.carijournals.org

The need to maintain political neutrality was emphasized in the United Kingdom by the Official Secrets Acts of 1911 to 1989, which stressed that a civil servant may not disclose sensitive government information. A civil servant is therefore, barred from publicly expressing political viewpoints, and must be seen to conform to the principle of anonymity. The system thus, demands loyalty to the structure and to constituted authority, and a clinical distancing from personal inclinations in policy leanings and policy formulations. This requirement is a major observance in the public service, the civil service and in university administration.

\subsection{Functions and Practice of Administrative Managers and Executives in Nigerian Universities}

A corporation is a meeting place for the principal-owner, the agents and the shareholders. In their transactions, targets are set, goals are met, and challenges are surmounted jointly, using shared paradigms and set down rules. Corporate governance is a collection of mechanisms, processes and relations used to control and operate a large business concern. It is enmeshed in a structure that ensures distribution of rights and responsibilities among the workforce, such that a shared vision and mission is attained. This regulatory structure, this connecting fabric that aligns divergent interests, mitigate conflicts, and solves emerging problems between the principal-agent (top-level management), the principal-principal (middle-level management) and the multiple-principal (lower-level) elements in business corporations provides a viable construct for the university system to emulate.

The committee system which has remained firmly entrenched in the governing structure of the university had continued to regale and uphold the doctrine of superior arguments, aggregation of opinions and formulation of ideas in the decision-making processes of our universities. Since management is,

"...the process of getting things done through other people," and through the sharing of responsibilities in a coactive manner (Mary Parker Follet, 1941, p.34), and

“...without necessarily standing on their necks" (Awoyemi, D.O., 2017, p.2),

it therefore, demands a lot of tact, skills and expertise to manage, shepherd and convince a number of people from different backgrounds to deliver on set goals; and steer them towards where they ought to be, as against where they want to be. This approach emphasizes human relations (Social/leader-member exchange) over time and measurement approach (Frank and Lillian Gilbreth, 1917). A successful manager is one who is able to put to effective use, the "top-down approach," the "bottom-up approach" or the "goals-down plans-up approach" (Adepoju Adeleke, 2001, pp. 17-18) to deliver on organizational goals. While the top-up approach (theory $\mathrm{X}$ ) in management policy is the policy which rests on the premise that people dislike work cedes management planning and decision-making efforts to the top-level, the bottom-up approach (theory Y) believes that decision-making is more effective and honest when it is made participatory and all-embracing, hence, planning is conceived from the lowerlevel, silted and fine-tuned by the middle-level, and endorsed by the top-level management. The goal is always, to modify the work to fit the man, and not the man to fit the work (Adepoju Adeleke, 2001). At this rate, injury, discomfort and disenchantment are minimized. The contrapuntal goals-down, plans-up approach is a two-way traffic that emphasizes the setting of organizational goals by top-level management, and leaves the process of how to achieve the set goals to evolve from lower-level management, to make the flow complementary (Adepoju Adeleke, 2001). 
Journal of Education and Practice

ISSN 2520-467X (Online)

Vol.5, Issue No.2, pp $30-44,2021$

www.carijournals.org

Luther Gulick and Lyndall Urwick (1937) in their submission on management ideas, captured in a nutshell, the basic management tools for administrative managers and executives, building on Henri Fayol's modern scientific management principles. Apart from providing corporate leadership, heralding core standards and upholding the vision and mission, the armamentariums of a modern executive in the university or in a corporate setup include (p)lanning, (o)rganizing, (s)taffing, (d)irecting, (co)ordinating, (r)eporting and (b)udgeting. The posdcorb acronym is a classic view of organizational practice that succinctly defines management and public administration through the functions they perform.

University administration is a diverse business that includes planning, registry, finance, human resources, estate management, public relations, etc. (Neil Harris). Educational administration and management harness human and material resources to supervise, plan, coordinate and implement policies and procedures for institutions. The intensive activities involved in effectively managing the complex university estate provide the necessary operational support to ensure stability of the structure, and provide leverage to enable the university meet its mandate. They also ensure compliance to procedures, and synergy of the overall mechanism. In a highly competitive and globalized marketplace, it has become expedient to be versatile in more areas of administration and to be able to adjust adequately to the demands of multitasking. The need to remain relevant in an eclectic workspace with meteoric demands make the following features the appurtenances of management culture:

\subsection{Planning:}

The demand of the job requires that the administrative executive should be alert to the need for planning. It is germane to plan and organize schedules for the effective running of the system, while affirming relevance by becoming the repository of the rules and regulations to guide the process of decision-making;

\subsection{Communication:}

Organizational teamwork and communication skills provide the needed ballast in educational administration and management. The executive who represents more than one entity at all times especially, with regards to front-desk image-making, displays sterling communication skills which is put to use at all times. It is pertinent to keep in mind the need to mint positive impressions in all interactions, as the interlocutor for the system. Versatility on this field is therefore, a sine qua non;

\subsection{Management:}

Educational administration is about management of time and people. This feature remains the raw material used to deliver and to remain relevant in a highly competitive economy. Managing human capital such that conflict is minimized remains an important requirement, hence, energy should necessarily be diverted towards maintaining good working relationships and promoting team spirit for maximum delivery;

\subsection{Information Technology:}

Management ethics in the contemporary and globally competitive space cannot do without digital relevance. It is a known fact that massive digital engagement in workspace culture has re-defined the nature of modern productivity and service-delivery. In educational administration and management, digitization and constant updating of knowledge is germane. Computer literacy is therefore, not negotiable; 
Journal of Education and Practice

ISSN 2520-467X (Online)

Vol.5, Issue No.2, pp $30-44,2021$

WWW.carijournals.org

\subsection{Teamwork:}

For planning, implementation and management of complex educational framework, teamwork is inevitable. Areas of strength, weakness, opportunities and threats are explored with a view to surmounting all challenges and achieving the vision/mission initiatives;

\subsection{Commercial Awareness:}

In this era of dwindling subventions from government-owner, it is unwise to insist on making university business an exclusive responsibility of government. In this regard, it has become expedient for universities and other HEIs in this clime to be commercially aware, negotiate the best deal and understand the market. Global competition and healthy rivalry have taken over the workspace with the upsurge in the numbers of private competitors. It is therefore, necessary to be meticulous and innovative in order to remain relevant as the format is fast-becoming more commercially-oriented. Fundraising, informative literature, groundbreaking research, good investments, currying the alumni and vivid internationalization are all parts of the marketing $\operatorname{mix}$;

\subsection{Committee System:}

According to Breach (1975), administration is a management process that involves carrying out procedures to execute plans, programmes and achieve set goals in a system. University administration is therefore, a set of procedures designed to achieve set targets in order to facilitate learning, research and community services. Administration in the university runs through the committee system. Quoting W.J.N. Mackenzie, Adefemi defined a Committee as

"... a body of people meeting round a table to take decision for joint action on behalf of a large body of which it is the Committee" (2008, p.2).

It is the consensus that merits of the committee system far outweighs its demerits in the decision-making process as it helps in fast-tracking decisions that otherwise could have taken a longer time in reaching with a larger group. It therefore eases the process of decision-making. Besides, in line with the usual parlance that "two heads are better than one," it gives room for contributions from a number of people and allows for wider scope of alternative views to be considered in order to reach a far-reaching conclusion. It is believed that a decision taken via the committee system is likely to have been well debated, and that because of this well thoughtof process, there would be rooms for in-depth and all-inclusive decisions that would aid effective delivery.

\subsection{Challenges}

Ethics and corporate governance in our universities have degenerated in standards, due to abstruse practices and obnoxious handling of actions and processes:

\subsection{Undue Interference}

Subjecting the knowledge corporation to government-cadre policies and imposing such policies on the universities have been known to do much harm than good. The university enterprise is a peculiar organization with structure and line operations that are unique in nature. Bringing it under a constricted civil service format would naturally restrict it and limit its delivery. Micro knowledge factories are not known to serve as appendages of political kingdoms. The horse-trading, skulduggeries and shenanigans that politics in this part of the world is known for should naturally be kept away from the frontiers of knowledge. Undue interference of politics and infiltration by politicians always leave the terrain poisoned and incapable of delivering on its mandates of teaching, research and community service. Since appointments of chief executives and governing councils are done by the sitting government, 
Journal of Education and Practice

ISSN 2520-467X (Online)

Vol.5, Issue No.2, pp $30-44,2021$

www.carijournals.org

appointees are naturally answerable to government and see themselves as gatekeepers for government. Thus, political considerations take preeminence over academic culture, and political considerations contend actively with loyalty to the educational system (Ogunruku, 2020). Another example of daunting interference could be found with the discretionary admission list where Chancellors and Pro-Chancellors are allotted admission slots and merit is downplayed to accommodate their candidates. Regulatory agencies like the NUC also superimpose administrative and structural fiats on the universities, notwithstanding their peculiar structure and their differences when compared to other sectors. Contending interests of stakeholders is therefore immersed and encroached on by the supervisory interest of government (Issa Abdulraheem et al);

\subsection{Excessive Bureaucracy}

Bureau pathology in an organization stultifies creativity. It is a known fact that excessive bureaucracy remains one of our greatest challenge in the universities, whereby new efforts are discouraged, and old ways and manners are maintained either because "...that is what the rule says..." or because "...that is the way we have been doing it..." Coupled with this is the phobia for new knowledge and new ways of confronting challenges. The fear of technology by the older generation and the misplaced and undue distrust in digital practice is unprecedented, hence, the perpetuation of manual, stressful and dreary work culture;

\subsection{Financial Opacity}

Lack of transparency in financial practice of tenured principal officers had contributed negatively to the image of distrust in a number of universities. Fetish administration, whereby, business of governance are enwrapped in undue secrecy, and financial records are not rendered as and when due, naturally ignites the wild imagination of the underfed workforce towards information epidemics especially, where there are outstanding financial commitments which had not been met. Also, the Internal Audit Unit is a mechanism for internal control structure of the finances of the universities. It is a known fact that this important control structure is more often than not, overpowered by management, thus, rendering it inept and incapacitated. External auditors are not spared, as they also are not independent of management influence (Abiola, 2012);

\subsection{Inadequate Civic Engagements and Intellectual Terrorism}

Key determinants of university rankings include teaching, research, knowledge transfer and international outlook. In all aspects mentioned, our corporate governors in the universities had mostly fallen flat, making the rankings of our universities hit rock-bottom. It is on record that outlook in these areas used to be better, which explained why the rankings were better. Sterling services through teaching and groundbreaking research used to be the norm, while our international outlook was enhanced by foreign students and visiting scholars. Most universities nowadays, are guilty of turning a blind eye to repression and intellectual terrorism whereby young scholars are subdued in matters of promotion, and forced to prune down numbers of papers so as not to appear to be contending with older Professors with lesser papers and bilious territories. Low international student mobility and lack of international collaborations had robbed us of the halcyon shine. A monumental drop in these positive activities and also, in the town-gown initiatives had taken a negative toll on the image of our universities;

\subsection{Over-centralization, Stress and under-employment}

Over-concentration of activities in administrative circles had been the bane of administration in the universities. In some universities, the Vice-Chancellors amass powers to themselves that are not captured under the rules and statutes. They live like feudal lords and would prefer to ground the system when they are not immediately available to perform their functions. Such 
Journal of Education and Practice

ISSN 2520-467X (Online)

Vol.5, Issue No.2, pp $30-44,2021$

www.carijournals.org

Vice-Chancellors see decentralization as a threat and would rather stall the system than conceding functions to their immediate vicegerents. In the same vein, the registry of some universities is constricted while all important professional activities are highly concentrated in Central Administration and a few other sectors. As a result, administrative activities become coaxed and limited to specific nerve-centers like Personnel Affairs, Academic Affairs, Council Affairs, etc., while other constituent parts are left partially unengaged. Studies in LMX theory (an offshoot of social exchange theory), have shown that supervisors usually choose who they like among the subordinates, and assign greater roles to them, while they assign lesser roles to those who are less liked or less capable (Dienesch and Liden, 1986). In Nigeria, the opposite is what obtains. Here, supervisors assign lesser roles to liked and mostly ineffective subordinates to compensate affiliations, and condemn the effective ones with no personal affiliation to "concentration camps" with supernumerary schedules. They are stretched, stressed and bear degenerative health hazards, while their colleagues have a field day in other arms of administration. This situation is worsened by under-employment whereby, the workforce is systematically reduced and a few people are left to do the jobs of retired or irresponsible officers who get promoted as and when due despite glaring inefficiencies;

\subsection{Incessant strikes and outdated academic structure}

Strike is fast becoming a culture in our universities. Like the popular totemic sign, it keeps going round and round ad infinitum, and has assumed a Cyclopean level whereby, it is expected as a necessary and inevitable disruption on our academic calendars. Strikes mostly in public universities, had imposed many defects on our academic standards and image, and all stakeholders, are culpable. The appalling injuries registered on our image as a nation calls for a revision of these disruptive trends, and the necessity to fathom other means to register legitimate concerns. Also, academic programmes for most universities in Nigeria are effete as most of them still brandish programmes formed for colonial agenda. More attention should therefore, be given to fashioning the programmes along unique selling points (USP) for broader relevance;

\subsection{Corruption and Brain-drain}

Like locusts, corruption which had eaten deep into facets of life in our macro-culture has gradually found its ways into some Ivory Towers. It is disheartening to note that the supposed lighthouses had been infected as news emanating from them had suggested. Bribery, lobbying, extortion, cronyism, sex-for-marks, graft and embezzlement have become recurring decimals in some universities, while despite glaring challenges, a number of them still struggle to uphold standards. Replays of stark malfeasance in the universities is undoubtedly, an attack on the repositories of knowledge. In search of standards and economic sustenance, dedicated scholars and professionals had jetted out of the shores to better climes, where practices are supported with good structures. Brain- drains for Nigeria has therefore become brain-gains for other nations especially the western world, where their exploits are harnessed to benefit these foreign nations;

\subsection{Colonial Education Curriculum}

In British tropical dependencies, the main curriculum of the colonial government was to produce clerks and interpreters for ecclesiastical assignments. Thus, when Fourah Bay College (Sierra Leone) was established in 1827, the primal interest was to mass-produce white-collared native officers to serve the church. The colonial education system placed premium on the production of manpower for the church and consequently, for the civil service, as natives were not necessarily trained to take up manual and practical work in their communities (W.O. Ibukun $\&$ A. Aboluwodi, 2010). This sentiment whereby graduates of universities and other HEIs wait 
Journal of Education and Practice

ISSN 2520-467X (Online)

Vol.5, Issue No.2, pp $30-44,2021$

WWW.carijournals.org

endlessly for white-collar jobs has its antecedents in the colonial education curriculum, and has posed a challenge to our constricted bureaucracy.

\subsection{Recommendations}

\subsection{University Autonomy}

Institutional autonomy and academic freedom are two sides of a coin. While the former emphasizes self-governance and unfettered freedom to manage the universities' internal affairs, the latter underlines individual freedom to impart knowledge, decide what knowledge to research and what ideas to propagate. According to Akinwunmi and Olaniyan (2001), autonomy invariably involves freedom to self-govern, to appoint key officers, to determine conditions of service of employed staff, to control admission and curriculum, and to control finances and regulate the institutions as legal entities. However, in a situation where our universities are financially dependent and are heavily subsidized by government, striking a balance between universities and government might be a difficult task to achieve (Dlamini, 1996). The totalitarian stance of government towards autonomy is only traceable to the fact that the universities are fiscally indebted to it and as such, cannot claim unhindered independence. To effectively generate knowledge and exhibit untainted scholarships, it is expedient for universities to be treated to a great measure of autonomy and academic freedom;

\subsection{Modern Management Techniques}

To eschew excessive bureaucracy, modern management techniques should be adopted. Discouraging bureau pathology in the system requires training and re-training, as well as the enshrinement of speed of administrative actions in the system. It is necessary to adopt business format in administrative process in order to encourage client-focused delivery and performance-based algorithms, where key-performance indicators are used for effective and efficient service- delivery. Technophilia must be promoted over technophobia in our work culture, and effete rules and regulations reviewed from time to time to complement contemporary realities;

\subsection{Transparency/Open-door Policies}

On issue of finances, it is only rational to forestall trouble and banish distrust by encouraging transparent and open-door policies in the universities. To entrench trust, the led should have constant access to information, while all stakeholders should be treated as partners in progress;

\subsection{Civic Alliances/Internationalization}

In view of growth in hostilities in host communities where resident universities fought with host communities for one reason or another, it is obvious that the importance and relevance of Ivory Towers to host communities have been lost on the pedestrians in recent times. This may be due to a number of reasons spanning from absence of impactful projects in the communities affected, to the inability to feel or grasp the relevance of higher institutions in the world views of town folks. It is therefore necessary to embark on aggressive propagation of knowledge in these defective areas so as to entrench positive change in the host communities, and rebuild in them sense of ownership. Also, it is high time our universities embark on linkages and exchange programmes with renowned foreign universities and integrate internationalization programmes to make our universities relevant and competitive in the global space;

\subsection{Knowledge Management}

The knowledge factories in our clime have been operational for long without internalizing the dynamics of knowledge management. Knowledge management (KM) emphasizes the maximization of intangible assets of an organization in a socioeconomic environment. While Karl Marx was engaged with the aspect of the unequal distribution of wealth engendering "a never-ending competition for finite resources," (Karl Marx, 2021), Charles Savage (1996) 
Journal of Education and Practice

ISSN 2520-467X (Online)

Vol.5, Issue No.2, pp $30-44,2021$

www.carijournals.org

identified three phases of socioeconomic development, underscoring a shift from agricultural age of the mediaeval times when wealth was constructed around ownership of land, through the industrial age when wealth was about ownership of capital (factories), to the modern knowledge age, when ownership of knowledge and effective use of knowledge to deliver goods and services constitute wealth. Thus, contemporary history prioritizes knowledge over ownerships of lands and factories, hence, there has been a marked shift from the industrial era to knowledge era, as the new definition of wealth in contemporary reality is constructed around knowledge. In a knowledge-based economy, managing assets in the workplace goes beyond floating periodic seminars and trainings to a total re-alignment of the workforce through onthe-job discussions, experience and know-how, formal apprenticeship, skill training and development, and most importantly, mentoring. Knowledge economy in this respect, charges you to know what you know, know what you don't know, know what you need to know, and know your goals in order to enhance productivity. It is an all-embracing science that looks beyond the scope of staff development units in their present shades, to one that requires the coordinative acumen of a Chief Knowledge Officer (CKO), as being done in advanced western organizations), tasked with the responsibility of managing intangible assets in the workforce;

\subsection{Work-life Balance/Reward System}

Since teamwork, cooperation and hive-mindset are the required features in managing organizations, it is important to begin to see the workforce not as mere human tools, but as people with needs and legitimate concerns. It is inevitable that due to the complex nature of organizations like our universities, work volumes expectedly, are immense, and stress amassed through demands, deadlines and neck-breaking pace of work. Stress builds up through underemployment, self-mismanagement, constricted timelines and other means (Bakare, K.A.). Importantly, the individual should be able to strike a balance between work and life in order to avoid health hazards or sudden death. Occupational stress should be minimized and people should be urged to manage their time better, prioritize tasks, delegate responsibilities, make out time for relaxation, and be conscious of their health. Also, to motivate and enhance productivity, tangible and intangible rewards should be considered for exceptional performances;

\subsection{Training the next Generation of Administrative Managers and Executives}

In Nigeria, training university administrative personnel is mostly left to chance. Most administrative executives learn on the job and through the rule-of-thumb, while few attempts are made to teach knowledge through formal erudition. To make matters worse, the dearth of training programmes, conferences and workshops for employed workers had created a closed system and a cul-de-sac that stifles the growth of knowledge of young executives. At the point of employment, graduates of behavioral science and the arts are recruited en masse. These people, who have never been exposed to any form of organizational practice are oblivious of what to expect, and are basically left to flow with the tide of the job, with much depending on the whims and caprices of their immediate bosses, i.e. how good or otherwise their first points of contact turn out to be. As the present-day administrative executives are thrown into the middle of multi-faceted occupational challenges, it is inevitable that some form of formal training should be required to build and strengthen administrative skills. Undergraduate and graduate programmes in Higher Education Administration are alien to the curricula of some universities, while short-term, in-service trainings are also becoming rare, courtesy of financial downturns. It is a known fact that the university is different and peculiar in structure, objectives, and processes, hence, the need for specialized knowledge in HE administration; 
Journal of Education and Practice

ISSN 2520-467X (Online)

Vol.5, Issue No.2, pp $30-44,2021$

WWW.carijournals.org

\subsection{National Policy on Education}

The National Policy on Education in Nigeria should be re-aligned to meet the needs of the $21^{\text {st }}$ century. Though recent development shows that awareness is being created in entrepreneurial education, more needed to be done in this area. The various aims of education, i.e. social aim, cultural aim, moral aim, intellectual aim, and most especially, vocational aim should be underlined in the policy to make it impactful and encyclopaedic. The individual must be taught to respect the dignity of labour and deploy knowledge and skills acquired through education to become selfreliant;

\subsection{Digital Revolution}

The future is digital. Technological advancement has aided activities and has enhanced it with neatness, speed of action and information. In modern times, the workspace culture is taken over by massive digitalization. Hence, to remain relevant, professionals have to embrace the growing avant-garde culture by constantly updating knowledge of emergent trends, and evolving from routinized careerists to new-age professionals. Bureaucracy is moving towards a paperless dispensation in our universities, and a rounded professional should hasten to move with it;

\subsection{Consultancy Services and Virtual Administration}

The beauty of any vocation is its relevance and viability after retirement. It is a known fact that one could decide to continue living on one's experiences garnered during active service by going into consultancy services which ensures knowledge transfer and promotes the replication of best practice. In addition, a new trend of administration is coming on board, which in the nearest future, may even impact on the general employability records in the universities and other organizations. Virtual administration is a concept that encourages the setting up of independent offices that are e-compliant and can provide diverse administrative services to organizations expectedly at reduced rates. It is a new office-concept that minimizes the number of staff and maximizes profit for more than one organization at a time in a virtual environment.

Lastly, university administration is an expansive and a flexible field that throws up new challenges by the day, best experienced by the individual professional. Most of the tricks of the job are learnt on the job and experienced first-hand. These can be published into books and pushed forward as bestsellers by the individual who is in service or has retired, as a source of lifetime income.

\subsection{Conclusion}

We have been able to probe issues bordering on ethics, pragmatics, and corporate governance in our universities. We have underlined the degradations and deprivations of the workforce, as well as influences that have impacted negatively on practice and activities in our universities. We attempted to trace in a nutshell, the colonial antecedent of university administration. We argued that this colonial apercu largely provided a framework for the modern civil service cum university administration practice. In the final analysis, we submitted that there was the need to update and upgrade ethics, structures, knowledge-system and corporate governance with a view to repositioning our universities for global competitiveness.

\section{DEDICATION}


Journal of Education and Practice

ISSN 2520-467X (Online)

Vol.5, Issue No.2, pp $30-44,2021$

www.carijournals.org

Obafemi Awolowo University, Ile-Ife, Nigeria celebrates her $60^{\text {th }}$ anniversary (JuneDecember, 2021). This paper is dedicated to excellence and distinction which the University has achieved over six decades, in spite of drowning challenges.

\section{REFERENCES}

Abiola, J. (2012). Corporate Governance in Nigerian Banking Sector and Relevance of Internal Auditors. Business Journal of Arts and Social Sciences, 5(1), pp. 66-74.

Adefemi, S.L. (2008). How to Conduct Meetings: The Role of A Secretary in a Committee System of Administration and Basic Skills in Minutes and Reports Writing. A paper delivered at a capacity building workshop for Administrative Executives in Kwara State University, Nigeria.

Adepoju Adeleke (2001). Management Concepts and Applications. Published by Concept Publications. Lagos. ISBN 978-2309-86-9.

Akinwumi, F.S. and Olaniyan, D.A. (2001), Analysis of University Autonomy in Nigeria.

African Journal of Educational Management, 9(2), pp.117-129.

Algo D. Henderson, Joseph Adwere-Boahmah, and Katharine Kunst. (1970). Training University Administrators: A Programme Guide. United Nations Educational, Scientific, and Cultural Organization (UNESCO), ISBN-10 923100882X, ISBN-13 978-9231008825, Paris. Awoyemi, D.O. (2017). Adherence to Vision and Mission as Tools for Effective Leadership: Obafemi Awolowo University as a Case Study, presented at a workshop for Provosts of Colleges, Deans of Faculties, Heads of Departments and Faculty Secretaries on $16^{\text {th }}-17^{\text {th }}$ October, 2017.

Azim, M.T. (2016). Corporate social responsibility and employee behavior: Mediating role of organizational commitment. Revista Brasileira de Gestao de Negocios, 18(60), Retrieved July 14, 2021, from https://www.redalyc.org/pdf/947/9476409003.2.pdf .

Bakare, K.A. (2019). University Administrators as Endangered Species: The Nigeria's Situation. Global Journal of Human Resource Management, European-American Journals, ECRTD-UK, Print ISSN: 2053-5686, 7(4), pp. 55-69, (Print), Online ISSN: 2053-5694 (Online), https://doi.org/37745/gjhrm.2013.

Bakare, K.A. (2021). Unions, Government and the University Enterprise in Nigeria. British Journal of Education, European-American Journals, ECRTD-UK,

Print ISSN: 2054-6351. 9(3), pp.106-119, (Print), Online ISSN: 2054-636X (Online), https://doi.org/10.37745/bje.2013.

Blau, P. (1964). Exchange and Power in social life. New York: Wiley.

Breach, E.F.L. (1975), The Principles and Practice of Management, published by Longmans Publisher, New York.

Dare, L.O and Oyewole, A. (1976). Review of Western State Civil service 1967-74,' published in The Quarterly Journal of Administration (eds.) M.J. Balogun \& Harry A. Green. Vol. x, no. 2, pp. 127-136.

Demidenko, E. and McNutt, P.A. (2010). The ethics of enterprise risk management as a key component of corporate governance. International Journal of Social Economics, ISSN 03068293, 37(10), pp. 802-815, https://doi.org/10.1108/0306829.

Dienesch, R.M. and Liden. R.C. (1986). Leader-Member Exchange Model of Leadership: A Critique and Further Development. Academy of Management Review, 11, 618-634.

Dlamini, C.R.M. (1996). University autonomy and academic freedom in South Africa. Thesis submitted in accordance with the requirements for the degree of Doctors of Laws at the University of South Africa. 
Journal of Education and Practice

ISSN 2520-467X (Online)

Vol.5, Issue No.2, pp $30-44,2021$

www.carijournals.org

Gilbreth, F.B. and Gilbreth, L.M. (1917). Applied Motion Study; a collection of papers on the efficient method to industrial preparedness, www.archive.org

Gulick, L.H. (1937). Notes on Theory of Organization. L. Gulick and L. Urwick (eds.), published in 'Papers on Science of Administration,' New York: Institute of Public Administration.

Henri Fayol (1949). General and Industrial Management (trans.), published by Sir Isaac Pitman \& Sons Ltd., (original work published 1918).

Her_Majesty's_Civil_Service,www.civilservice.gov.uk.

Ibukun, W.O. and Aboluwadi, A. (2010). Nigeria's National Policy on Education and the University Curriculum in History: Implication for Nation Building. Journal of Education and Practice, ISSN 2222-1735 (Paper), ISSN-288X (Online),1(2), pp. 9-17.

Issa Abdulraheem, Abdulrahman Muammed and Othman Yeop Abdullah (2014). Corporate governance in Nigerian Higher Education: Issues and challenges, European Journal of Business and Management, ISSN 2222-905 (Paper), ISSN 2222-2839 (Online).6(2), pp. 221228, Retrieved, July 17, 2021.

Karl Marx (2021). Karl Marx and Conflict. https://www.books.google.com

Lord Lugard (1922). The Dual Mandate in British Tropical Africa, published by Frank Cass \& Co. Ltd., Abingdon, Oxon, OX14 4RN by arrangement with William Blackwood \& Sons Ltd. Manzoni, J. and Barsoux, J. (2002). The Set-Up-to-Fail Syndrome. How Good Managers Cause Great People To Fall. Boston: Harvard Business School Press.

Metcalf, H.C. and Urwick L. (eds.) (1941). Dynamic Administration: The Collected Paper of Mary Parker Follet, published by Harper and Row, New York.

Molm, L.D. and Cook, K.S. (1995). Social exchange and social networks. In K.S. Cook, G.A. Fine, and J.S. House (Eds.) Sociological perspectives in social psychology. (209- 235).

Boston, M.A.: Allyn and Bacon.

Neil Harris, University Administration. www.goggle.com .

Ogunruku, Ayorinde. (2012), University Administration in the $21^{\text {st }}$ Century, published by the Obafemi Awolowo University (OAU) Press Ltd. Ile-Ife, Nigeria. ISBN 978-136-052-6.

Ogunruku Ayorinde. (2020), That our universities may thrive. Published in The Nation newspaper, August 19, 2020.

Okonjo, I.M. (1975), The Functions and Responsibilities of Secretaries to the Military Government. Published in The Quarterly Journal of Administration. (eds.) M.J. Balogun \& Harry A. Green. 10(4) pp. 431-440.

Savage, C. (1996), Fifth Generation Management, Boston: Butterworth-Heineman 